\title{
Working
}

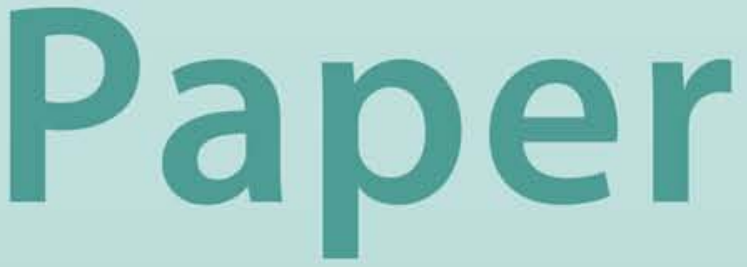




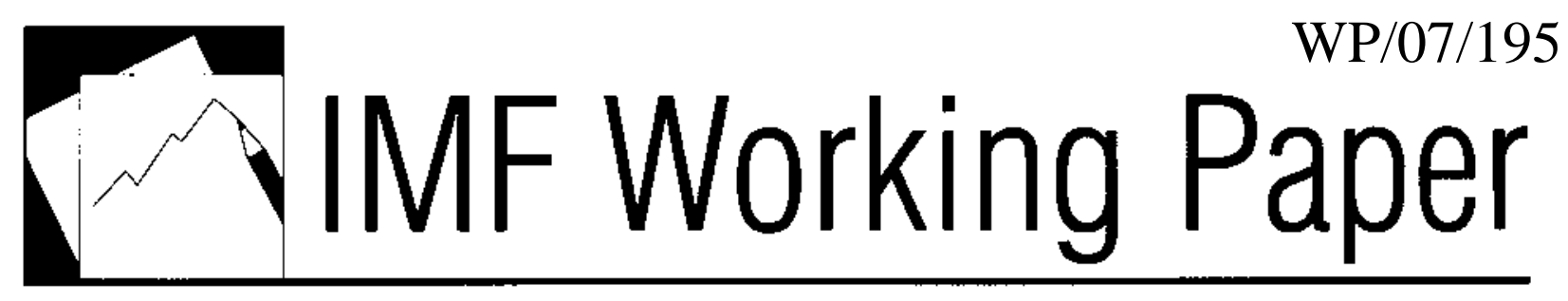

\section{New Landscape, New Challenges: Structural Change and Regulation in the U.S. Financial Sector}

Ashok Vir Bhatia 


\title{
IMF Working Paper
}

\author{
Monetary and Capital Markets Department \\ Western Hemisphere Department \\ New Landscape, New Challenges: \\ Structural Change and Regulation in the U.S. Financial Sector ${ }^{1}$ \\ Prepared by Ashok Vir Bhatia
}

Authorized for distribution by Tamim Bayoumi and Carlos Medeiros

August 2007

\begin{abstract}
This Working Paper should not be reported as representing the views of the IMF.

The views expressed in this Working Paper are those of the author and do not necessarily represent those of the IMF or IMF policy. Working Papers describe research in progress by the author(s) and are published to elicit comments and to further debate.
\end{abstract}

Given the rapid evolution of the U.S. financial sector and attendant regulatory challenges, this paper explores ways to fine-tune U.S. oversight arrangements. It surveys the financial landscape, separating a highly regulated, multi-business, and (in terms of relative asset holdings) shrinking "core" from a lightly regulated, more specialized, and rapidly expanding "periphery”; explains the U.S. regulatory philosophy and structure, with its focus on core institutions and its jurisdictional complexity; highlights certain new challenges, without presuming to have all the solutions; draws out some broad policy implications, from the “30,000 foot level”; and concludes by tabling and discussing one, specific, reform idea.

JEL Classification Number: G28

Keywords: Financial Sector, Financial Stability, Regulation, Supervision

Author’s E-Mail Address: abhatia@imf.org

\footnotetext{
${ }^{1}$ The paper builds on an earlier version of same title published as Chapter IV in United States-Selected Issues, IMF Country Report 07/(forthcoming), pp. 15-36 (Washington: International Monetary Fund). The author thanks Tamim Bayoumi for overall guidance.
} 


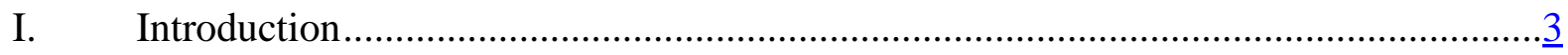

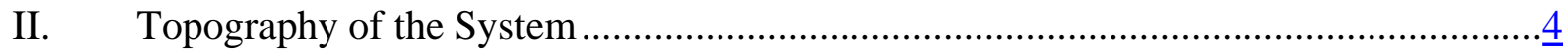

III. Regulatory Philosophy and Structure …............................................................ $\underline{8}$

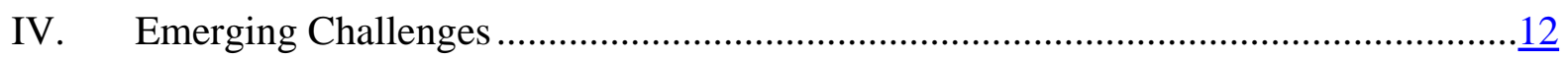

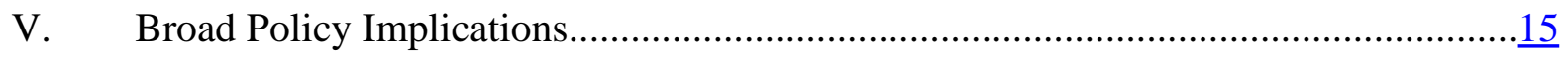

VI. Specific Policy Considerations ........................................................................... 17

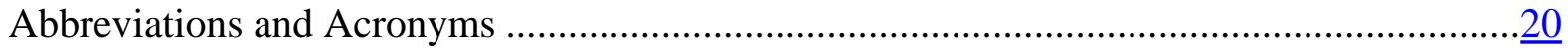

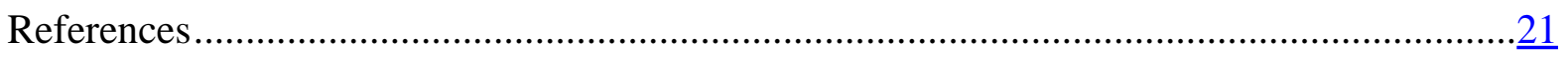

\section{Figures}

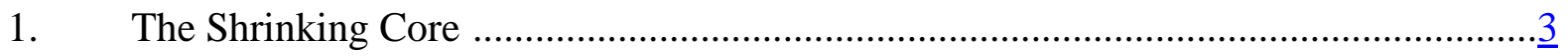

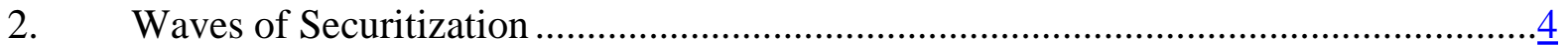

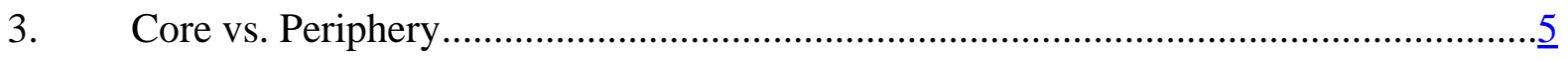

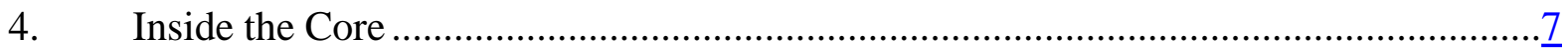




\section{INTRODUCTION}

1. The rapid evolution of the U.S. financial sector is creating new challenges for the regulatory structure. With large financial institutions increasingly distributing loans to investors rather than holding them, the share of financial sector assets owned by insured depositories - which, along with a few large investment banks, form the focus of U.S. prudential supervision-has fallen from around half in 1980 to under one-quarter in 2006 (Figure 1). Thus, in a period during which the complexity of instruments and trades has multiplied, the portal through which the Federal Reserve views and influences financial markets on a day-to-day basis has, in one respect, halved in size. As we shall argue, however, parsimony in the application of safety-and-soundness oversight has been a key factor supporting innovation in the U.S. financial system.

\section{Reflecting the}

Administration's increased emphasis on regulatory effectiveness, this paper explores ways to fine-tune U.S. oversight arrangements. It surveys the financial landscape, separating a highly regulated, multi-business “core” from a lightly regulated, more specialized "periphery” (Section II); explains the U.S. regulatory philosophy and structure, with its focus on core institutions and its jurisdictional complexity (Section III); highlights certain new challenges, without presuming to have all the solutions (Section IV); draws out some broad policy implications, from the "30,000-foot level"

(Section V); and concludes by tabling and discussing one, specific, streamlining measure (Section VI).

\section{Figure 1. The Shrinking Core}

As insured depositories originate to distribute, their share of system assets has halved in $\mathbf{2 5}$ years.

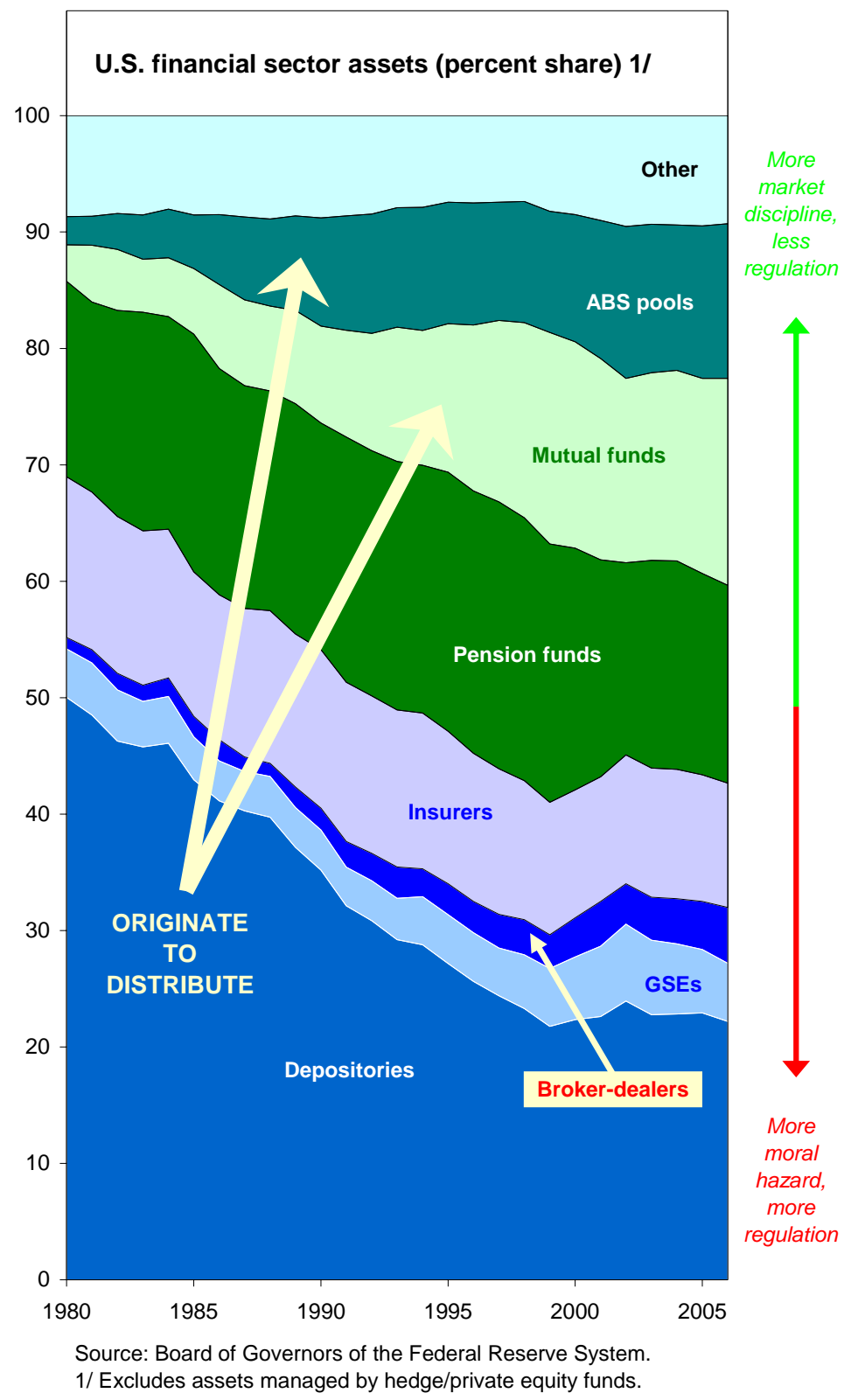




\section{TOPOGRAPHY OF THE SYSTEM}

3. With mass-production techniques doing to finance what they did to manufacturing a century ago, new instruments are shaping a new landscape. Spurred by competition and investor demand, large financial firms are harnessing the power of IT, marrying complex modeling techniques and innovative legal structures to generate a growing array of securities with diverse risk profiles. Consumer credit scoring allows automated approval of housing, consumer, and student loans which, along with more-heterogeneous business and commercial real estate loans, are increasingly bundled together as securities (Federal Deposit Insurance Corporation (FDIC), 2006). Waves of securitization, flowing from one asset class to the next, have created new

opportunities and-as we shall discuss-new challenges (Figure 2).

\section{Reflecting the} technological changes, special purpose vehicles are among the fastest growing holders of financial assets. Also referred to as assetbacked security (ABS) pools, these pass-through structures serve as "obligors," issuing debt backed by cash flows on the assets that they own. With

Figure 2. Waves of Securitization Beginning with mortgages, pooling techniques have spread from one asset class to the next.

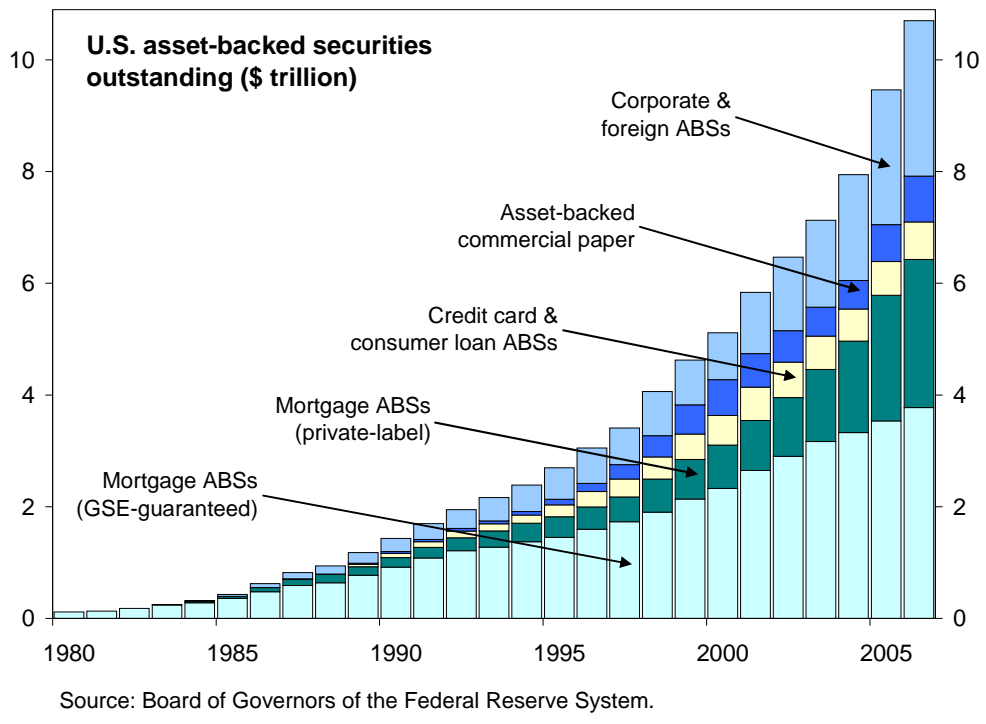

those assets enjoying legal safe-harbor from any previous owner's bankruptcy, the creditworthiness of each ABS issued is a function of two, and only two, factors: the quality of the assets in the pool, and the capital structure (Moody's Investors Service, 2007, and Standard \& Poor's, 2007a,b).

5. ABS pools can and do transform "junk" assets into investment-grade liabilities, thereby widening their investor bases to include pension funds and foreign central banks. Working with the rating agencies, arrangers assemble securities known as collateralized debt obligations (CDOs), with four principal forms of credit enhancement: credit "wraps” (guarantees or insurance); "excess spread” (lower interest rates on liabilities than on pooled assets); "over-collateralization” (lower volumes of liabilities than of assets); and payment "waterfalls" (seniority/subordination hierarchies). The result is a range of "bespoke" assets, suited to diverse investor preferences: typically, a 'AAA'-rated tranche protected from all but the most extreme losses, for the risk-averse investor; a speculative-grade "equity” tranche with "embedded leverage," for the yield-hungry; and a "mezzanine” slice in between. 
6. Hedge funds are key providers of liquidity in the new markets, and the result is a finer pricing of risk. As the nimblest, best-tooled investors in the system, hedge funds are major contributors to trading volume, particularly in the higher-risk segments, and are therefore central to price discovery (FitchRatings, 2007). They are also, generally, wellequipped to cope with mounting instrument complexity-assets backing CDOs may be whole loans or bonds, but increasingly are ABSs, other CDOs (creating "CDO²s" and “CDO ${ }^{3} \mathrm{~s}$ ”), or credit default swaps (CDSs, creating "synthetic” CDOs).

7. More complexity, however, entails more ratings dependency. Reflecting asset correlations - or overly "coarse" or otherwise imperfect ratings_CDO tranches often provide more yield than identically rated single-name securities (Bank of England, 2007, and Citi, 2007). While hedge funds generally are able to dissect and analyze the "idiosyncratic risks” posed by complex CDO structures, there is evidence that securitization is fostering greater reliance on ratings, as a simplifying force, by less sophisticated investors-especially at higher rating levels (Bank for International Settlements (BIS), 2005b). That, as we shall discuss, is placing increasing responsibility on a small group of private rating agencies.

\section{The diverse array of institutions that make up the financial sector can be separated} into a highly regulated “core” and a lightly regulated "periphery” (Figure 3):

- $\quad$ The core consists of institutions for which market discipline is relatively weak and those considered systemically important: all federally insured depositories (7,380 commercial banks, 1,270 thrifts, and 8,362 credit unions), the governmentsponsored enterprises (GSEs) active in mortgage securitization and investment (Fannie Mae and Freddie Mac), and the largest brokerdealers (organized into the "big five" investment banking groups). This core now holds less than one-third of total financial sector assets.

- $\quad$ The periphery consists of all other financial entities, a space in which the cost of funds serves as the principal check on risk-taking: small broker-dealers

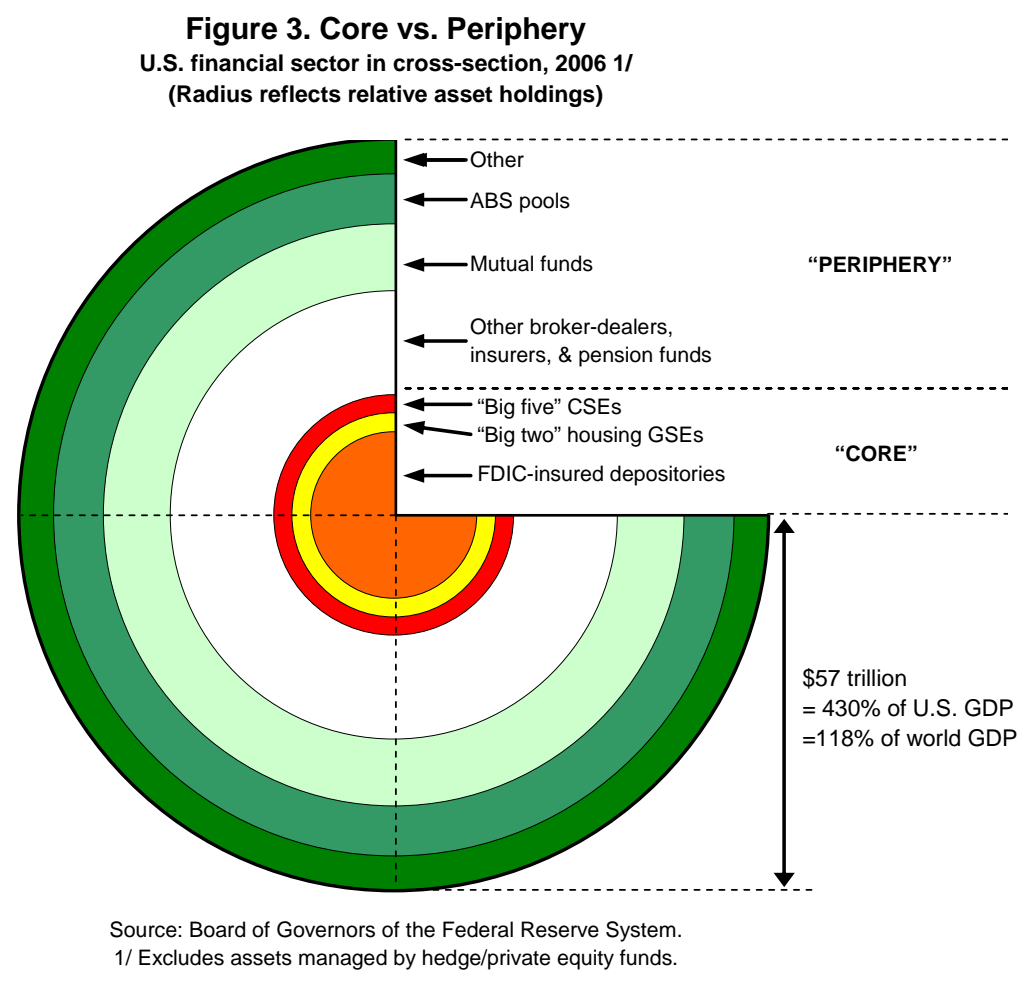


and all insurance companies, finance companies, mortgage companies, funding corporations, and private capital pools, the latter ranging from pension funds and mutual funds to real estate investment trusts, ABS pools, hedge funds, and private equity funds. As the core has contracted in relative size, the periphery's role as a holder and originator of financial assets has grown, with ABS pools, mutual funds, and hedge/private equity funds leading the expansion in the former, and mortgage brokers and hedge/private equity funds in the latter.

\section{Further distinctions can be drawn, however, between large and small core} institutions, as they pursue different business strategies. The 20 largest bank holding companies (BHCs) — which together account for some two-thirds of BHC assets - dominate the banking industry's retail business, originating residential mortgages and consumer loans on a "production line" that often includes specialized (and largely unregulated) nonbank lenders within their group structures (a practice also followed by the large investment bank holding companies). The thousands of regional and community banks, thrifts, and credit unions, conversely, are increasingly left with niche business, much of which is small-scale commercial real estate and business lending with a higher premium on local knowledge.

10. While small banks still hold most loans they make, large core institutions' embrace of the "originate-to-distribute" model has created new sources of income (Figure 4). Large commercial banks not only originate many loans for the explicit purpose of securitization and sale, they also purchase a pipeline of loans from other originators for the same reason. Large investment banks are similarly engaged in loan purchases for bundling, and are taking market share in syndication. While most of the structured securities are distributed to the periphery, servicing rights on the pooled loans (collections and workouts) are typically retained by commercial banks, such that servicing fees exceed bundling fees at the largest BHCs. The result is revenue diversification through a growing stream of noninterest income, which has cushioned the impact of tight net interest margins in recent years, supporting profitability, capital ratios, and various market-based metrics of solvency (Bhatia, 2006).

\section{The periphery, characterized by even greater diversity than the core, serves as a} shock-absorber. Given their more specialized nature, many institutions in the periphery come and go without attracting wider notice. Scores of hedge funds have done so in recent years. Similarly, the monoline mortgage origination industry, after accounting for more than half of subprime originations in 2005-06, has born the brunt of the so-called "early payment defaults” in that segment, but problems have remained isolated (Kiff and Mills, 2007). In many respects, the periphery can be argued to be a natural repository for credit risk from the core (Kroszner, 2007, and Kuritzkes, Schuermann, and Weiner, 2003). To cite but a few examples, insurers, with their event-based exposures, sell CDSs to diversify risk; pension funds are far less leveraged than commercial banks; and yield-hungry hedge funds are key buyers of CDO equity and key sellers of protection against speculative-grade credit risks. 
Figure 4. Inside the Core
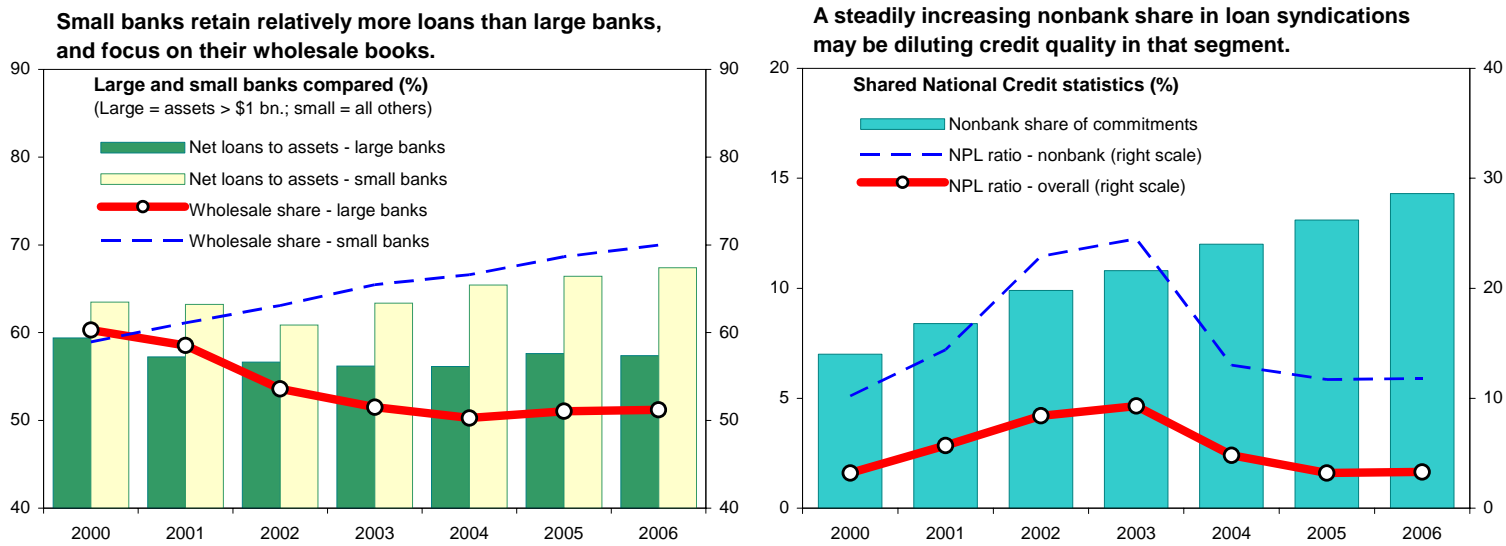

Noninterest income has supported profits at the largest BHCs, offsetting tight net interest margins...

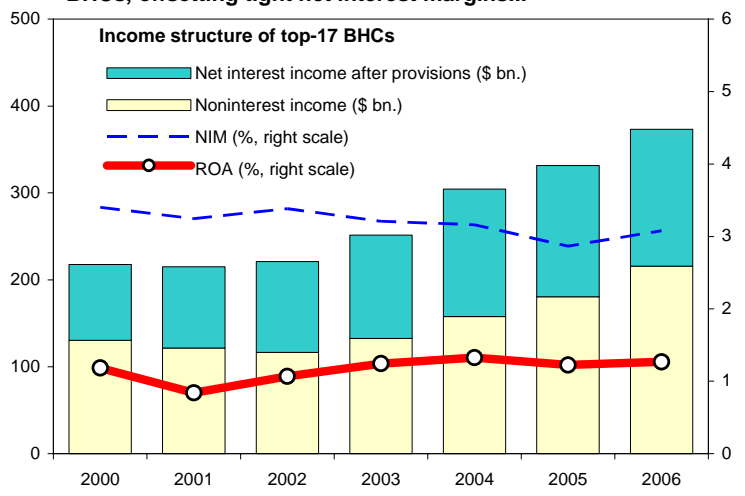

...with income from financial services activity dominating.

Noninterest income of top-17 BHCs, 2002-06 average

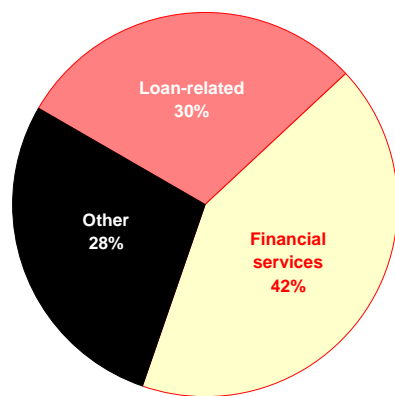

On one market-based measure, soundness continues to improve at the most important core institutions.

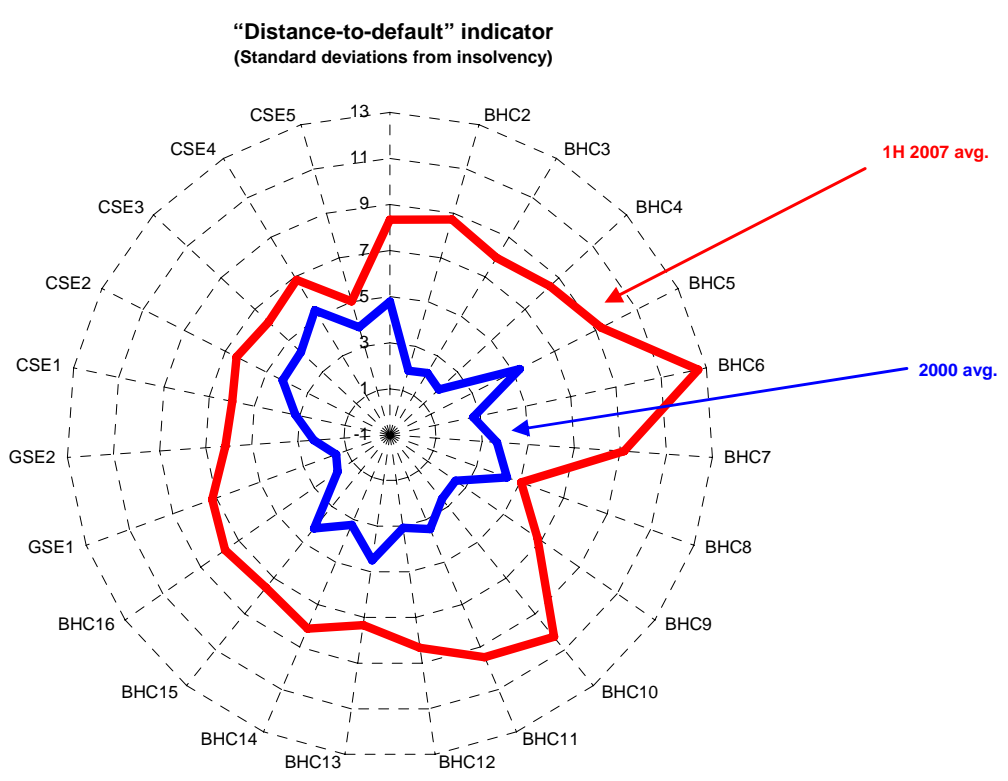

Sources: Board of Governors of the Federal Reserve System, BHC Performance Reports and Shared National Credit surveys; Datastream; FDIC, call reports; and Fund staff estimates (following the methodology in De Nicoló, Hayward, and Bhatia, 2004). 
12. New markets have transformed the core's risk management, with liquidity risk and counterparty credit risk assuming greater importance. Loan books are being actively managed, like bond portfolios, with institutions able to choose between selling loans (whole or bundled) or retaining them (and therefore the relationships) while buying CDSs (Bassett and Zakrajšek, 2003, and Fed, 2003). Both strategies, however, rely on continuous liquidity in new markets yet to be tested by a "tail event." Additionally, CDS purchases and the provision of "prime brokerage" services to hedge funds require understanding the exposure dynamics to and creditworthiness of entities in the periphery that may furnish only limited information, placing renewed emphasis on collateral (Cole, Feldberg, and Lynch, 2007).

13. The core and periphery coexist symbiotically, with key players maintaining group structures that straddle both. Large BHCs range from those that are "bank centric," focusing on deposit-taking, origination, and servicing (most of them), to those more "broker-dealer centric,” emphasizing securitization, fund management, derivatives dealing, prime brokerage, and proprietary trading (a few institutions). Similarly, the "big five” investment bank holding companies, in addition to securities broker-dealing, prime broking, and securitization, are active in syndication and the provision of financing to both bank and nonbank loan originators-and own deposit-taking subsidiaries known as industrial loan companies (ILCs), a type of state-chartered, FDIC-insured commercial bank.

\section{Regulatory Philosophy AND Structure}

\section{The U.S. regulatory philosophy, as enunciated by the Fed, is emphatic that} supervising the entire system is neither feasible nor desirable. Arguments for limiting the reach of safety-and-soundness regulation and supervision include the need to avoid bestowing "halo effects" upon entities that would go on to advertise themselves as important enough to be federally supervised and sound as a result of such oversight; the need to avoid cramping innovation; and pure practicality, given the complexity of the system and the fact that many institutions in it are internationally mobile (Bernanke, 2007a,c).

15. Two tests of the need for safety-and-soundness oversight are applied:

- $\quad$ Presence of moral hazard, referring in the first instance to all commercial banks, thrifts, and credit unions, because insured depositors have "little or no incentive to evaluate the risk-taking of their bank" (Bernanke, 2007a), and the "big two" housing GSEs, "because of the belief of market participants that the U.S. government will back these institutions under almost any circumstances” (Bernanke, 2007b).

- $\quad$ Systemic importance, referring specifically to "very large commercial and investment banks" that "may not fully account for risks to general financial stability," as well as to the need to prevent "failures of risk management by ... a sufficient number of smaller [institutions, that] would threaten not only the solvency of the institutions themselves but also the health of the whole system” (Bernanke, 2007c). 
16. Only the "core" of the system is prudentially supervised, therefore, with the doctrine emphasizing "confidence in the invisible hand" of market discipline elsewhere (Kohn, 2007a). Examination authorities extend to all federally insured depositories (and their holding companies and group affiliates, except in the case of some ILCs), the "big five" investment banking groups, and the housing GSEs. In part, small depositories are included out of the recognition, given past experience, that they may bear systemic importance collectively if not individually. Even in this highly regulated core, however, regulators stress the value of a "hybrid system that supplements direct regulation with a substantial amount of market discipline” (Bernanke, 2007a), with supervision “designed to limit—not eliminatethe risk of failure” (Greenspan, 2005a).

17. Prudential oversight seeks to work with market discipline by emphasizing capital, receivership, and disclosure requirements (Bernanke, 2007a). Capital is viewed not merely as a cushion to absorb losses and (in the case of the depositories) to protect the deposit insurance funds, but as assurance that shareholders have their own money at stake, with incentives to control risk buttressed by linking capital requirements to risk-taking. Credible, automatic wind-up provisions are seen as central to ensuring that shareholders and uninsured creditors believe they will take losses in the event of failure, with prompt corrective action prohibitions on regulatory forbearance and least-cost resolution requirements (again for depositories) introduced through the FDIC Improvement Act (FDICIA) of 1991. Disclosure, in turn, is addressed through an extensive system of consumer protection, discussed below.

18. “Too-large/complex-to-fail” institutions attract special correctives. On the one hand, the fact that certain large commercial banks may warrant special treatment is recognized in law, with the FDICIA including a "systemic risk exception” to its least-cost resolution requirement. On the other hand, with uninsured noncore liabilities and capital as the marginal sources of funding for large BHCs (and the main sources for large investment banking groups), market discipline retains an important policing role over even the largest financial institutions (Bernanke, 2007b). Two other safeguards are in place:

- $\quad$ The systemic risk exception in the FDICIA was intentionally made difficult to invoke, requiring agreement by two-thirds of the FDIC Board, two-thirds of the Fed Board, and the Secretary of the Treasury "in consultation with the President" (Eisenbeis, Frame, and Wall, 2004).

- $\quad$ Since the 1990s, the Fed has had in place a Large Complex Banking Organization program, which focuses on risk-management policies, procedures, and controls on a continuous basis, with each institution in the program assigned a dedicated team of examiners (DeFerrari and Palmer, 2001).

19. Supervisory powers have progressively been extended to the owners and affiliates of depositories. Consolidated supervision reflects a growing consensus that financial conglomerates need to be supervised as they are managed, at the enterprise level, with due attention to cross-cutting legal, reputational, and operational risks-as a supplement to more 
traditional reliance on the legal compartmentalization of the group structure. Accordingly, the BHC Act of 1956 introduced group-level supervision of BHCs; the Financial Institutions Reform, Recovery, and Enforcement Act of 1989 addressed consolidated supervision of thrift holding companies; and the Gramm-Leach-Bliley Act of 1999 added “umbrella” supervision of financial holding companies (expanded-scope BHCs).

20. Consolidated supervision of financial holding companies, BHCs, and thrift holding companies focuses on "ring-fencing" risks to insured depositories. The BHC, Financial Institutions Reform, Recovery, and Enforcement, and Gramm-Leach-Bliley Acts all emphasize "risk-focus," mandating examiners to ensure that holding companies and affiliates do not pose unacceptable risks to depositories within the group. The difference may appear subtle, but supporting the soundness of nonbank affiliates is not a core part of the mandate, and examination authorities over such entities are invoked sparingly.

\section{Group-level supervision of the "big five" investment banks reflects a broader} emphasis on systemic risk. Under the Glass-Steagall Act of 1933, repealed in 1999, the U.S. system maintained a somewhat unique separation between commercial and investment banking. As such, it took an E.U. Directive (requiring all financial conglomerates operating in the European Economic Area to be subject to consolidated supervision) to catalyze the launch, in 2004, of the Consolidated Supervised Entity (CSE) program for large investment banking groups. That program, however, has no specific mandate to protect deposit-taking ILCs within the group, emphasizing instead the systemic risks posed by "a small number of institutions ... [that] are the principal dealers in the over-the-counter derivatives markets and ... the leading clearing firms for exchange-traded derivatives" and that "also originate securitized assets ... provide financing to other originators, and often provide financing to the buyers of those assets, including buyers of the riskiest tranches” (Kohn, 2007a).

\section{The "big two" housing GSEs are also systemically important-and pose a delicate} policy challenge. They remain the largest U.S. mortgage investors, with prepayment risk hedging operations that leave them similarly dominant in the over-the-counter interest rate swaption market. On the one hand, their agency charters (which include contingent credit lines from the Treasury) give rise to the widely held presumption that their debt enjoys the backing of the U.S. government-resulting in low and relatively risk-insensitive funding costs that create incentives for them to leverage and expand their balance sheets. On the other hand, stricter oversight of the two entities could be perceived by markets as a deepening of federal involvement. Reflecting the latter concern, the Treasury and the Fed have argued that any effective GSE reform would need to be a package deal encompassing higher capital requirements, legislatively enshrined receivership provisions, and measures to limit the size and scope of their investments (Bernanke, 2007b, Greenspan, 2005b, and Snow, 2005).

\section{Consumer and investor protection are fundamentally different from prudential}

oversight. Here, the emphasis is on disclosure, fairness, and fraud-prevention through conduct-of-business rules to underpin effective market discipline. Lenders to households are 
subject to disclosure requirements (and certain prohibitions) under the Truth in Lending Act (TILA) of 1968 "to assist in shopping for credit" (Fed, 2000). Registered broker-dealers face a "net capital rule" under the Exchange Act of 1934 "to protect consumers and other market participants from broker-dealer failures and to enable those firms that fall below the minimum net capital requirement to liquidate in an orderly fashion" (Federal Register, 2004). Insurers, in turn, face a range of state-level regulations. Enforcement, however, includes a prominent role for private right of action, i.e., lawsuits, including class actionsrequiring especially meticulous rulemaking to avoid "paralysis by litigation."

\section{In the application of conduct-of-business rules, distinctions are made based on the} sophistication of the parties involved. Whereas retail depositors are seen to lack "the time and resources to gather information," institutions and high-wealth individuals are generally regarded as "well equipped to assess" risks, with "the clout to demand the information they need” (Bernanke, 2007a). Principles-based approaches, therefore, are considered most appropriate for sophisticated players - hence the safe-harbor provisions under Rule 144A of the Exchange Act (which created an unlisted, limited-disclosure securities market restricted to "qualified institutional buyers") and similar exclusions for high-net-worth individuals (which created the hedge/private equity fund space). More rigid, rules-based methods, in contrast, are considered better-suited to protecting small players, including homeowners.

25. Reflecting state powers, past experimentation, and a raft of inherited compromises, the U.S. oversight structure includes five independent federal regulators of depositories (Government Accountability Office (GAO), 2004):

- $\quad$ The Fed, founded in 1913, is umbrella supervisor of financial holding companies (some 650 of them), lead supervisor of BHCs $(5,129)$, and joint primary supervisor of state banks that are Fed members (892) along with the states.

- $\quad$ The FDIC, created in 1933, is joint primary supervisor of state nonmember banks (4,783 including ILCs) and state thrifts (433), back-up supervisor of all other banks and thrifts, and insurer of all banks and thrifts (including branches of foreign banks).

- $\quad$ The Office of the Comptroller of the Currency, established in 1863 as a financially autonomous bureau of the Treasury, is charterer and primary supervisor of national banks (1,705), and primary supervisor of U.S. branches of foreign banks (12).

- $\quad$ The Office of Thrift Supervision, established in 1989 as an autonomous bureau of the Treasury, is lead supervisor of thrift holding companies (481), charterer and primary supervisor of federal thrifts (837), and joint primary supervisor of state thrifts (433).

- $\quad$ The National Credit Union Administration, set up in 1970, is chartering authority and supervisor of federal credit unions $(5,189)$, and insurer of all federal and most $(3,173)$ state credit unions.

26. In addition, a number of functional regulators are vested with important roles. The Securities and Exchange Commission (SEC) supervises the five CSEs on a consolidated 
basis under its "alternative net capital rule," while enforcing an investor protection regime for some 5,100 other broker-dealers on a stand-alone basis under its original net capital rule. The Office of Federal Housing Enterprise Oversight supervises the "big two" housing GSEs. The insurance industry is regulated exclusively by the states. The Fed writes TILA regulations for all lending to households, but shares the enforcement authority with other federal regulators of depositories, the Federal Trade Commission, and the states. Finally, an artificial line is drawn between the securities and futures markets, with the SEC, the states, NASD, and exchanges regulating the former, and the Commodity Futures Trading Commission, the states, the National Futures Association, and exchanges covering the latter.

27. Safety-and-soundness oversight employs a range of tools. As supervisors, the five federal depository agencies, occasionally in concert with the SEC, articulate principles in interagency "guidances" that are applied flexibly, on a case-by-case basis, under examination authorities. As regulators, they adopt rules, e.g., the Basel packages currently under review, that "prescribe and proscribe what must be done and what may not be done in specific areas" (Greenspan 2005a). Guidances and rules alike are promulgated through a deliberate process of interagency consensus-building, proposal, public comment, modification, and finalization. Finally, as noted, discretion is limited by the prompt corrective action provisions of the FDICIA, with mandatory interventions once certain capital thresholds are breached.

28. Agencies are bound together by institutionalized coordination mechanisms. As members of the Federal Financial Institutions Examination Council (FFIEC), the five federal regulators of depositories jointly propose principles, standards, and reporting forms. Coordination with the states is achieved through the participation in the FFIEC of a representative of the State Liaison Committee, a body comprising the Conference of State Banking Supervisors, the American Council of State Savings Supervisors, and the National Association of State Credit Union Supervisors. Coordination with the functional regulators, in turn, is achieved primarily through the Fed's authorities over financial holding companies and BHCs, with the Large Complex Banking Organization program including arrangements for joint inspections of nonbank institutions within the group structure.

\section{Safety-and-soundness and conduct-of-business examinations have different} approaches and emphases. In the former, examiners are prudential supervisors, acting preemptively and enjoying considerable flexibility. In the latter, the focus is on compliance, enforcement, and the setting of examples with ex post punishment. Whereas the bank, thrift, and credit union agencies—including at the state level—have substantial prudential experience, the SEC, with its CSE program still relatively new, remains on a learning curve.

\section{EMERging Challenges}

30. The changing incentives for risk-taking under the originate-to-distribute model are creating new challenges. On the one hand, the model is facilitating the transfer of credit risk from the financial system's systemically important core to its more atomized periphery, 
which, per se, should support soundness. On the other hand, by separating the originators and bearers of risk, it may be exacerbating information asymmetries — creating a new, hitherto less than fully appreciated, "principal-agent problem” whereby originators have incentives to embed more risks in capital structures than investors expect, notwithstanding information support from rating agencies. The changing incentives, in turn, could be amplifying procyclicality in lending standards. Perhaps most importantly, from a systemic perspective, the model is changing rather than eliminating risks in the core, with liquidity risk and counterparty risk emerging as new focal points for intermediaries and supervisors alike.

\section{Underwriting standards, in particular, may be losing some stringency in response} to the changing incentives. Originators and securitizers are exposed to early payment default risk, reputational risk, and "warehousing risk" (the risk that a sudden drying up of investor demand could leave them with pipelines of unwanted loans pending packaging, with some CDOs reportedly taking up to 120 days to assemble). In extreme cases such as the subprime bust, there is also an element of political risk. Despite these restraints, however, generous fee structures for intermediaries, and investor remoteness from any potential liability associated with the origination decision, create incentives to persist with the risk-taking for as long as the "good times last." Thus, although rating agency models stipulate minimum standards for the assets in each pool, originators may satisfy them more in letter than in spirit, focusing on “observables” at the expense of intangibles such as due diligence in underwriting.

\section{Part of the recent deterioration in credit standards may also be a by-product of} newer securitization techniques. Arguably, with sophisticated methods of disassembling and reassembling risks resulting in more investor demand than might otherwise have been the case, and with CDO production requiring a wide and varied range of assets as feedstock, the more recent developments in securitization may have encouraged lending in various new and more risky niches. Thus, in the residential mortgage market - despite several guidances to depositories reiterating prudent underwriting principles- “risk-layering” practices grew sharply in 2005-06, with many loans combining adjustable-rate, interest-only, lowdocumentation, and multiple-lien features. As noted in the accompanying staff report, a similar cycle may be playing out currently in the leveraged loan market, with a proliferation of “covenant-lite” loans to finance leveraged buyouts (IMF, 2007).

\section{In the current cyclical downswing in the subprime mortgage market, more novel} securitization techniques may also be limiting workout flexibility. While it remains relatively straightforward to restructure distressed assets in single-class ABS pools, the same does not apply to multi-class CDOs. Here, the creditworthiness - and ratings - of different tranches rest on carefully stacked seniority/subordination hierarchies and other risk mitigants, such that modifying nonperforming assets in the pool is somewhat akin to removing the bottom dominos from a pile. Again, principal-agent problems come into play, with the investor owning only a small fraction of the lien on the overstretched mortgagee's home. In an estimated one-third of CDO structures outstanding, servicers are barred, by indenture, 
from restructuring more than 5 percent of the assets in the pool, without regard for whether or not cooperative solutions represent the least-cost course of action (UBS, 2007).

34. Ratings dependency is increasing. Arguably, in the assembly of complex CDO transactions, the raters are becoming active participants rather than arm's-length assessors of risk (Mason and Rosner, 2007). As their rating (and consultancy) fees grow, so too do their incentives to facilitate expanding volumes of CDO issuance. Although the Credit Rating Agency Reform Act of 2006 is introducing certain, modest, checks on agency conflicts of interest, other official initiatives — such as the Basel IA capital rule for depositories-would cement the agencies' role as “delegated regulators” (SEC, 2006, and Federal Register, 2006). Policies to catalyze greater rating competition are frequently cited as a remedy but, with the industry often considered a "natural oligopoly," measures to promote more due diligence by investors may ultimately prove more fruitful (Bhatia, 2002).

35. Mounting competition from the periphery is also an issue for the core. Senior loan officers at large commercial banks have consistently cited increasing competition from nonbanks as a driver of easing credit standards (Fed, 2007a,b). In one recent Fed survey, several respondents noted explicitly that an interagency guidance proposed in early 2006 had had "little effect" on their commercial real estate lending decisions (Fed, 2007a). Abstracting from the specifics (the guidance had targeted small and midsize banks, not the large banks in the survey), it is to be expected that competition between variably regulated entities will create some pressures. In the current environment, with institutions in the periphery taking market share in origination in certain segments, the extent to which "regulatory intensity" needs to increase to maintain a given level of risk-taking in the core is an open question.

\section{Regulators have responded that the "three pillars" of bank soundness-capital,} origination skills, and diversification-remain as important as ever. Attention has centered on capital, as a source of strength and provider of critical lead time in the event of a disturbance. Implementation of Basel II represents a major effort to enhance the risksensitivity of regulatory capital requirements at the largest, most internationally active banks. While much of Basel II's focus is on relatively "traditional" risks, the notice of proposed rulemaking also addresses critical new challenges, for instance by devoting a whole chapter to advanced exposure-at-default modeling techniques for counterparty credit risk (BIS, 2005a, and Federal Register, 2007). The parallel Basel IA package, potentially covering all other depositories in the system, would be similarly beneficial, nowhere more so than in its more "granular" capital treatment of mortgages based on loan-to-value ratios.

37. Nonetheless, delayed implementation of Basel IA and Basel II can be cited as a key example of how multiple, overlapping agencies can slow response times (GAO, 2007). While the Fed sought to press forward with Basel II, the FDIC in particular expressed concerns about excessive reductions in capital requirements (FDIC, 2005, and Meyer, 1999). Ultimately, a compromise was agreed, including retention of the minimum "leverage ratio" (tier-1 capital to total assets); a "parallel run" in 2008; "transitional floors" in 2009-11 
capping capital reductions at 5 percent per year (relative to Basel I requirements); and a "holistic review" at the end of the transition period. While the dialogue may well have improved the product, it is worth noting that the equally important Basel IA package-with its likely disciplining effect on mortgage lending standards - was held up in the process, while (perhaps independently) subprime lending standards took a nosedive.

38. Regulators believe the overarching regulatory philosophy remains appropriate. With regard to the relative "shrinkage" of the highly regulated core and the implications for system oversight, the Fed makes a number of points:

- $\quad$ Regulators believe they retain the ability to substantially influence the system as a whole, because the largest and most important commercial and investment bankswhose balance sheet size provides an increasingly incomplete reflection of their true reach-are firmly inside the supervisory net (Samolyk, 2004).

- Extension of supervisory powers to new institutional categories could itself create risk, because "when the government singles out particular institutions or markets as being especially critical to the stability of the system, moral hazard concerns may well follow" (Bernanke, 2007c).

- Similar considerations apply to expanded information-gathering efforts, which are "unlikely to yield insights that can be acted upon and may create a false sense of comfort among market participants, which could make the system substantially more risky” (Kohn, 2007a).

39. The hedge fund space is an example of this approach. The Fed acknowledges that the industry is gaining in importance, as a key provider of liquidity and innovative trading strategies in several market segments (Kohn, 2007a, and Kroszner, 2007). Nevertheless, the Fed is steadfast in its position that restraints on the size and leverage of individual funds are best applied indirectly, by the large commercial and investment banks that serve as hedge funds' major counterparties, including through the provision of prime brokerage services (Bernanke, 2007a,c). Accordingly, the focus has been on measures to ensure that core institutions conduct sufficiently vigorous stress tests of their net, marked-to-market exposures to individual hedge funds, and maintain appropriately conservative netting arrangements and “margining” policies governing the taking of initial and daily collateral (Cole, Feldberg, and Lynch, 2007, and Embersit, 2007).

\section{BRoAd Policy IMPlications}

40. The U.S. financial sector has demonstrated a tremendous capacity for innovation, with large benefits for the economy as a whole. Its creative abilities, manifest in the steady stream of new financial products and services, have in recent years supported a widening of domestic credit availability financed increasingly by foreign savings. The relative ease with

which external capital has been attracted into the system represents a revealed preference by foreign investors for U.S. private debt securities (Balakrishnan, Bayoumi, and Tulin, 2007). 


\section{Although complacency would be misplaced, it would appear that innovation has} supported financial system soundness. New risk transfer markets have facilitated the dispersion of credit risk from a core where moral hazard is concentrated to a periphery where market discipline is the chief restraint on risk-taking. The conduit mechanism, in turn, has facilitated broader credit extension — with the important qualitative nuance that much of the recent credit growth has reflected lending to new, previously excluded borrowers, as opposed to "more money thrown at the same people" (Weinberg, 1995). Although cycles of excess and panic have not disappeared - the subprime boom-bust being but the latest examplemarkets have shown that they can and do self-correct.

\section{The key to innovation has been that market forces have been allowed to operate.}

The regulatory philosophy, from which our core-periphery distinction flows, has emphasized selectivity in the application of safety-and-soundness oversight—and in information gathering — with the Fed serving a singular role as guardian against more dirigiste temptations. A growing array of financial institutions has been made to function without the props and constraints of prudential norms and the counsel and intrusion of examiners, and many have become laboratories of innovation. Creative energy has flowed, moreover, from the interface between the core and the periphery, spurred by competition and cooperation.

43. Greater complexity has altered the nature of prudential oversight. With instruments such as the first-loss tranches of CDOs and index-based CDSs allowing investors to take on the risks and returns of leverage without recourse to borrowing, "effective leverage" has become a combination of traditional "financial leverage" and this relatively new "embedded leverage" (FitchRatings, 2007). On the one hand, such complications, coupled with the rapid expansion of off-balance sheet commitments, have rendered accounting statements increasingly incomplete reflections of complex financial institutions' activity. On the other hand, the more discriminating pricing of a wide range of risks has created a wealth of market information. Surveillance practices have adjusted accordingly, with the Fed, for instance, monitoring a broad range of price-based indicators (Nelson and Perli, 2005).

44. Inevitably, uncertainties remain. As the highly regulated core has contracted in relative size, the ability of regulators to influence-or even view-the entirety of the system has been reduced. With trading activities gaining prominence, and with liquidity in new markets yet to be tested comprehensively, concerns have centered on whether strong financial sector profits may be akin to those of the seller of an option, with a potentially large "payout" in the event of a major disturbance (Knight, 2007). The Fed, cognizant of this risk, has discussed the role of monetary policy in such a scenario (Kohn, 2007a):

- $\quad$ "Systemic events in market-based financial systems are perhaps more likely to involve price fluctuations and abrupt changes in market liquidity than are systemic events in depository-based financial systems. But ... such events can more readily be countered by macroeconomic policy instruments than could old-fashioned crises of depository intermediation.” 
- "Supplying additional liquidity and reducing borrowing costs can greatly ameliorate the effects of market events on the economy, and those types of macroeconomic interventions will carry less potential for increasing moral hazard than would the discount window lending that was a prominent feature of crisis management when depositories funded more credit.”

- $\quad$ "Market intermediated finance also requires us to live with less control and less knowledge than we had when banks were dominant. Greater uncertainty about where risks are lodged is the flip side of better dispersion of those risks, especially to less regulated sectors, and of more resilience of the whole system.”

45. Risk-focused supervision of a small number of systemically important institutions and measures to ensure rapid market clearing are becoming increasingly critical. The largest BHCs and investment banking groups are central to financial stability not only because issues at any one such entity could cascade across the system, but also because these firms serve as “regulators by proxy," policing risk-taking in the periphery. While the extension of direct prudential supervision to hedge funds, for example, may be infeasible and undesirable, indirect oversight through the BHCs and CSEs requires continuous vigilance. Measures to ensure the efficient functioning of payment and settlement systems are similarly important, to support the smooth flow of liquidity.

46. Given the stakes, it is legitimate to periodically review the regulatory structure. The U.S. multiple-agency model offers financial firms a unique level of choice as to how, and by whom, to be supervised - the "flipping" by banks from national to state charters or vice-versa is not uncommon - and there is little evidence to suggest that supervisory procedures are more effective when implemented under more centralized structures (De Nicoló, Hayward, and Bhatia, 2004). Nonetheless, the U.S. model raises important issues of consistency of treatment across markets and institutional categories, and requires careful interagency coordination to ensure that risks do not "slip between the cracks."

\section{Specific Policy Considerations}

\section{As discussed, the U.S. financial oversight philosophy has both facilitated and} withstood the tectonic shifts underway in the U.S. financial geography. Regulatory adjustments, therefore, are more likely to focus on organizational detail than on the scope of supervisory activity. As emphasized by the Administration, reforms need to be guided by clear principles to ensure focus and consistency across institutions and markets (Paulson, 2006). One such principle should be that initiatives be simplifying in nature. Another may well be that incremental refinements are preferable to (and more feasible than) more ambitious measures that could pose transition risks.

48. With the Fed bearing apex responsibility for U.S. financial stability, it is reasonable to ask whether it enjoys sufficiently broad oversight authorities. As indicated above, Fed preeminence among the multiple financial regulators is, in many respects, a sine qua non of 
the U.S. system. That, and the Fed's argument that first-hand financial sector information is a critical input to its monetary policy decision-making, suggests that the location of supervisory authorities over financial holding companies and BHCs is not up for discussion (Goodhart, 2000). Given broad agreement that the "big five” investment banking groups bear systemic importance, however — and given that they own insured depositories - the optimality of situating the CSE program at the SEC may form a reasonable question.

\section{The fact that not all groups that include ILCs are subject to consolidated supervision could, potentially, provide a segue into the broader issue of CSE oversight:}

- $\quad$ The Industrial Bank Holding Company Act of 2007 (H.R. 698), pending before the Congress, proposes to make new ILCs subject to broader prohibitions on the mixing of banking and commerce, while bringing their parents and group affiliates into the federal supervisory net. To do so, it proposes amending the FDIC Act to create a new institutional category, the "industrial bank holding company," under the consolidated supervision of the FDIC — an agency that, unlike the Fed, currently enjoys limited consolidated supervisory powers. As pointed out by the Fed, the principles of consistency and simplicity would be better served by amending the BHC Act to remove the various exceptions it created for ILCs (Kohn, 2007b).

- $\quad$ H.R. 698 proposes (and the Fed concurs) that holding companies currently owning ILCs - a set of institutions that includes the "big five" CSEs-be grandfathered under current legal provisions. While fair-treatment considerations and legal factors may require that this be the case, it is worth noting (hypothetically) that, absent grandfathering, amendments to the BHC Act could require the owners of ILCs to choose between divesting them or becoming BHCs under the consolidated supervisory authority of the Fed. If any of the major investment banking groups were to choose the latter option, important implications for the CSE program would follow.

- $\quad$ As noted earlier in this paper, the still-new CSE program is distinguished from other U.S. consolidated supervisory protocols in that it is not geared specifically to the risks that a group structure may pose to its insured depository subsidiaries-instead, there is a more general emphasis on the systemic risks posed by large complex entities that are agreed to belong in the highly regulated core. At the same time, as mentioned previously, a key difference between the CSE program and the regulation of registered broker-dealers is that the latter is an investor protection exercise whereas the former centers on prudential supervision - the CSE program shares important synergies with the Fed's BHC oversight, and in many respects sits oddly at the traditionally enforcement-oriented SEC.

- $\quad$ Reflecting all of the above, one significant organizational reform that may be worth more detailed study would involve the transfer of the CSE program from the SEC to the Fed, where it could be merged into longer-standing arrangements governing BHC supervision. Not only could such a move improve regulatory consistency-e.g., the CSEs are currently subject to a different variant of Basel II than that being developed 
for the depositories - it would also enhance the Fed's direct access to information on, and ability to influence the behavior of, five systemically important institutions that are central to the "indirect regulation" of various unsupervised entities in the periphery of the financial system.

- $\quad$ The GAO, in a 2004 report, weighed the pros and cons of rationalizing financial regulators along functional lines - the so-called "twin peaks" model (GAO, 2004). In a possible quid pro quo for the transfer of the CSE program from the SEC to the Fed, consideration could also be given to a "twin peaks-lite" transfer of TILA rulemaking responsibilities from the Fed to the SEC, which (in the U.S. context) is generally viewed to possess unmatched expertise in matters of consumer protection.

50. A menu of constructive ideas is available "off the shelf." While we believe the above-mooted functional reorganization could materially streamline U.S. financial oversight arrangements, it is merely one of several proposals in circulation. Others range from a succession of housing GSE reform bills_-none of which have addressed sufficiently the Administration's and Fed's well-grounded "halo effect" concerns - to a bill in 1995 that had sought to merge the SEC and the Commodity Futures Trading Commission-agencies with similar and converging missions, reflecting the "convergence of new financial instruments and trading strategies in the securities and futures markets” (GAO, 2004).

51. Ultimately, perhaps the greatest challenge for U.S. policy makers will be to achieve political consensus. As the Congress deliberates and crafts initiatives to ensure the continuing adaptation and evolution of the U.S. regulatory system-including some that could be resisted by one or the other agency-legislators will doubtless remain cognizant of the adage that "a regulator is only as powerful as those it regulates." 


\section{AbBreviations AND ACronyms}

ABS

"Big five” CSEs

"Big two" GSEs

BIS

$\mathrm{BHC}$

CDO

CDS

CSE

Fannie Mae

Fed

FDIC

FDICIA

FFIEC

Freddie Mac

GAO

GSE

ILC

SEC

TILA
Asset-backed security

The Bear Stearns Companies Inc. The Goldman Sachs Group, Inc. Merrill Lynch \& Co., Inc.

Morgan Stanley

Lehman Brothers Holdings Inc.

Fannie Mae

Freddie Mac

Bank for International Settlements

Bank holding company

Collateralized debt obligation

Credit default swap

Consolidated supervised entity

Federal National Mortgage Association

Federal Reserve

Federal Deposit Insurance Corporation

FDIC Improvement Act

Federal Financial Institutions Examination Council

Federal Home Loan Mortgage Corporation

Government Accountability Office

Government-sponsored enterprise

Industrial loan company

Securities and Exchange Commission

Truth in Lending Act 


\section{REFERENCES}

Bank of England, 2007, Financial Stability Report, Issue No. 21 (April).

Bank for International Settlements, 2005a, Basle Committee on Banking Supervision, “The Application of Basel II to Trading Activities and the Treatment of Double Default Effects” (July). , 2005b, Committee on the Global Financial System, “The role of ratings in structured finance: issues and implications” (January).

Bassett, W.F., and E. Zakrajšek, 2003, “Recent Developments in Business Lending by Commercial Banks,” in Federal Reserve Bulletin (December), pp. 477-492.

Balakrishnan, R., T. Bayoumi, and V. Tulin, 2007, “Globalization, Gluts, Innovation, or Irrationality: What Explains the Easy Financing of the U.S. Current Account Deficit?” IMF Working Paper 07/160 (Washington: International Monetary Fund).

Bernanke, B.S., 2007a, Federal Reserve Board, "Financial Regulation and the Invisible Hand,” Remarks at the New York University Law School (April 11). , 2007b, Federal Reserve Board, “GSE Portfolios, Systemic Risk, and Affordable Housing,” Remarks before the Independent Community Bankers of America Annual Convention (March 6).

, 2007c, Federal Reserve Board, “Regulation and Financial Innovation,” Remarks to the Federal Reserve Bank of Atlanta’s 2007 Financial Markets Conference (May 15).

Bhatia, A.V., 2002, “Sovereign Credit Ratings Methodology: An Evaluation,” IMF Working Paper 02/170 (Washington: International Monetary Fund).

, 2006, “U.S. Banking: Financial Innovation and Systemic Risk,” in United StatesSelected Issues, IMF Country Report 06/278, pp. 36-44 (Washington: International Monetary Fund).

Citi Global Markets Limited, 2007, Credit Products Strategy, “AAA Structured Credit Overview” (May 14).

Cole, R.T., G. Feldberg, and D. Lynch, 2007, "Hedge funds, credit risk transfer and financial stability,” in Banque de France Financial Stability Review-Special Issue on Hedge Funds, No. 10 (April), pp. 7-17.

DeFerrari, L.M., and D.E. Palmer, 2001, “Supervision of Large Complex Banking Organizations," in Federal Reserve Bulletin (February), pp. 47-57.

De Nicoló, G., P. Hayward, and A.V. Bhatia, 2004, “U.S. Large Complex Banking Groups: Business Strategies, Risks, and Surveillance Issues,” in United States-Selected Issues, IMF Country Report 04/228, pp. 72-86 (Washington: International Monetary Fund). 
Eisenbeis, R.A., W.S. Frame, and L.D. Wall, 2004, "Resolving Large Financial Intermediaries: Banks Versus Housing Enterprises,” Federal Reserve Bank of Atlanta Working Paper 2004-23a (October).

Embersit, J., 2007, Remarks at the Launch of the Bank of France's Financial Stability Review’s Special Issue on Hedge Funds (April 18).

Federal Deposit Insurance Corporation, 2005, “Maintain Current Leverage Ratio in New Basel II Framework, FDIC Chairman Recommends,” FDIC Press Release 112-2005 (November 10).

, 2006, “A New Plateau for the U.S. Securitization Market,” in FDIC Outlook (Fall), pp. 3-10.

Federal Register, 2004, “Alternative Net Capital Requirements for Broker-Dealers That Are Part of Consolidated Supervised Entities; Supervised Investment Bank Holding Companies; Final Rules,” Part II, Volume 69, No. 118 (June 21) , 2006, “Risk-Based Capital Guidelines; Capital Adequacy Guidelines; Capital Maintenance; Domestic Capital Modifications; Proposed Rules and Notice,” Part II, Volume 71, No. 247 (December 26).

, 2007, "Proposed Supervisory Guidance for Internal Ratings-Based Systems for Credit Risk, Advanced Measurement Approaches for Operational Risk, and the Supervisory Review Process (Pillar 2) Related to Basel II Implementation; Notice,” Part II, Volume 72, No. 39 (February 28).

Federal Reserve Board, 2000, “Truth in Lending,” Proposed Rule (December 19). _, 2003, Senior Loan Officer Opinion Survey on Bank Lending Practices (January). , 2007a, Senior Loan Officer Opinion Survey on Bank Lending Practices (January). , 2007b, Senior Loan Officer Opinion Survey on Bank Lending Practices (April).

FitchRatings, 2007, “Hedge Funds: The Credit Market’s New Paradigm,” Special Report (June 5).

Goodhart, C.A.E., 2000, “The Organisational Structure of Banking Supervision,” Financial Stability Institute, Bank for International Settlements, FSI Occasional Paper No. 1 (November).

Government Accountability Office, 2004, Report to Congressional Committees, "Financial Regulation-Industry Changes Prompt Need to Reconsider U.S. Regulatory Structure,” GAO-05-61 (October). , 2007, Report to Congressional Committees, “Risk-Based Capital—Bank Regulators Need to Improve Transparency and Overcome Impediments to Finalizing the Proposed Basel II Framework,” GAO-07-253 (February). 
Greenspan, A., 2005a, Federal Reserve Board, “Bank Regulation,” Remarks at the Independent Community Bankers of America National Convention (March 11). , 2005b, Federal Reserve Board, “Government-sponsored Enterprises,” Remarks to the Conference on Housing, Mortgage Finance, and the Macroeconomy, Federal Reserve Bank of Atlanta (May 19).

International Monetary Fund, 2007, United States-Staff Report for the 2007 Article IV Consultation, IMF Country Report 07/(forthcoming) (Washington: International Monetary Fund).

Kiff, J., and P. Mills, 2007, "Money for Nothing and Checks for Free: Recent Developments in U.S. Subprime Mortgage Markets,” IMF Working Paper 07/(forthcoming) (Washington: International Monetary Fund).

Knight, M.D., 2007, Bank for International Settlements, “Now you see it, now you don’t: risk in the small and in the large," Keynote Address at the Eighth Annual Risk Management Convention of the Global Association of Risk Professionals (February 27-28).

Kohn, D.L., 2007a, Federal Reserve Board, “Financial Stability and Policy Issues,” Remarks at the Federal Reserve Bank of Atlanta's 2007 Financial Markets Conference (May 16).

, 2007b, "Industrial Loan Companies," Testimony before the Committee on Financial Services, U.S. House of Representatives (April 25).

Kroszner, R.S., 2007, Federal Reserve Board, "Recent Innovations in Credit Markets,” Remarks to the 2007 Credit Markets Symposium (March 22).

Kuritzkes, A., T. Schuermann, and S.M. Weiner, 2003, "Risk Measurement, Risk Management and Capital Adequacy in Financial Conglomerates," in BrookingsWharton Papers on Financial Services edited by R.E. Litan and R. Herring (Washington: Brookings Institution Press).

Mason, J.R., and J. Rosner, 2007, "Where Did the Risk Go? How Misapplied Bond Ratings Cause Mortgage Backed Securities and Collateralized Debt Obligation Market Disruptions," in Mortgage-Backed Security Ratings (May).

Meyer, L.H., 1999, Federal Reserve Board, "Moving Forward into the 21st Century," Remarks at the Conference of State Bank Supervisors (June 3).

Moody's Investors Service, 2007, Testimony of Warren Kornfeld, Managing Director, Moody's Investors Service, before the Subcommittee on Financial Institutions and Consumer Credit, U.S. House of Representatives (April 17).

Nelson, W., and R. Perli, 2005, “Selected Indicators of Financial Stability,” paper presented at the Irving Fisher Committee's Workshop on Data Requirements for Analysing the Stability and Vulnerability of Mature Financial Systems (Ottawa: Bank of Canada). 
Paulson, H.M., 2006, U.S. Department of the Treasury, "Competitiveness of U.S. Capital Markets,” Remarks by the Treasury Secretary to the Economic Club of New York (November 20).

Samolyk, K., 2004, “The Evolving Role of Commercial Banks in U.S. Credit Markets,” in FDIC Banking Review, Volume 16, No. 2, pp. 29-65.

Securities and Exchange Commission, 2006, “Oversight of Credit Rating Agencies Registered as Nationally Recognized Statistical Rating Organizations,” Proposed Rule, Release No. 34-55231; File No. S7-04-07, RIN 3235-AJ78.

Snow, J.W., 2005, U.S. Department of the Treasury, "Proposals for Housing GSE Reform,” Testimony by the Treasury Secretary before the Committee on Financial Services, U.S. House of Representatives (April 13).

Standard \& Poor's, 2007a, Testimony of Susan Barnes, Managing Director, Standard \& Poor's Ratings Services, submitted to the Subcommittee on Securities, Insurance, and Investment, U.S. Senate (April 17). , 2007b, Structured Finance, U.S. Residential Subprime Mortgage Criteria (New York: Standard \& Poor's).

UBS, 2007, Conference Call, “Servicing in a Subprime Meltdown,” notes by R. McCaughrin (April 16).

Weinberg, J.A., 1995, “Cycles in Lending Standards?” in Federal Reserve Bank of Richmond Economic Quarterly, Vol. 81/3 (Summer). 